\title{
Sustainable Livelihood Strategies Rural Household in Sanden District Bantul Regency
}

\author{
Liana Fatma Leslie Pratiwi*, Ali Hasyim Al Rosyid, Maftuh Kafiya \\ Agribusiness Department, Faculty of Agriculture, Universitas Pembangunan Nasional Veteran Yogyakarta, \\ Jl. SWK 104 (Lingkar Utara) Condongcatur, Sleman, Yogyakarta 55283, Indonesia. Telp. (0274) 486733, Fax (0274) 4866188 \\ Email*: lianafatmaleslie@upnyk.ac.id
}

\begin{abstract}
People living in the countryside mostly have a profession as a farmer. Farming is one of the largest sources of income for rural households. In the district of Sanden, rural communities utilize a variety of land agroecosystems for agriculture. Utilization of various types of agricultural land agroecosystem is one of the household livelihood strategies. Livelihood strategies undertaken by rural communities aim to reduce poverty and improve household welfare. This research aims to (1) describe strategy of rural households to support the achievement of sustainable livelihoods (2) Knowing the inequality of farmers ' income distribution based on livelihood strategies used by rural households. The basic method used is a descriptive analytical method. The research site in Sanden district, Bantul regency was then taken by random farmer owners of 30 people as respondents. Rural household strategy to support sustainable livelihood achievement is calculated using descriptive statistics, and the inequality of farmer's income distribution based on livelihood strategies used by rural households is calculated using the Gini index and the Lorentz curve. The results showed that farmers ' household strategy to support the greatest sustainable livelihoods achievement in the form of consolidated strategies, and inequality of revenue distribution based on households livelihood strategies is moderate distribution inequality.
\end{abstract}

Keywords: Gini Index, inequality, livelihood strategies, rural household, Bantul Regency

\section{INTRODUCTION}

Bantul Regency is the biggest contributor to GRDP after Sleman Regency and Yogyakarta City, which is $18.81 \%$ (BPS of Yogyakarta Special Province, 2019). In Bantul Regency agriculture, forestry and fisheries sectors are the second largest contributors to the Gross Regional Domestic Product (GRDP) after the manufacturing industry at around $13.91 \%$ (BPS Bantul Regency, 2018). Despite being one of the biggest contributors to the GRDP for the Special Region of Yogyakarta, Bantul Regency is included in the poorest regions after Kulon Progo Regency (18.30\%) and Gunungkidul (17.63\%), namely 136,240 people or $13.57 \%$ of the poor.

Poverty is still concentrated in rural areas, this is because most of the poor in rural areas have low education and narrow agricultural land (Hermanto, 2017). However, rural communities continue to work hard to improve their standard of living through the agricultural sector. The agricultural sector is still a leading and economic base for rural communities. The agricultural sector plays a role in absorbing labor, creating jobs, reducing unemployment and poverty, and providing labor and food. Agricultural development must be focused on superior commodities by considering the suitability of the agro ecosystem in order to increase productivity and selling value (Mulyono \& Munibah, 2017).

Most of the people in Sanden Sub district, Bantul Regency work as farmers by utilizing agricultural land in various agro ecosystems for farming. The types of land used by farmers are paddy fields, dry fields and coastal land. Coastal land is the choice of the community to be used and functioned as a medium for agricultural cultivation because the area of coastal sand is very wide and has not been utilized optimally.

Utilization of various types of land agro ecosystems is carried out as a livelihood strategy undertaken by farmers to improve the welfare of their households. This livelihood strategy arises due to increasing household needs, poverty and low welfare in rural communities. With a livelihood strategy adopted by the community, poverty is expected to decrease and welfare will increase. A livelihood strategy is a step that everyone takes to be able to achieve the socioeconomic status conditions that are intended to be useful for a good life.

Low farm income and not being able to meet all the needs of farm households, causes some of the household members look for alternative sources of income, either by diversifying farming or by increasing the allocation of out-of-farm labor which ultimately increases the diversity of sources of diverse income sources affect the structure of farmer's household income, and will affect the distribution of farmer's household income. The structure and distribution of income will describe the level of welfare of farm households (Nasir, et.al., 2015)

Livelihood strategies that are commonly applied by rural farming communities are diversification, intensification, extensification, mobility, subsistence and off farm (Nurwidiani \& R, 2019). Communities in Sanden Sub district have implemented a livelihood strategy by intensifying and extending agricultural land 
by utilizing and managing coastal land for agricultural cultivation. The famous coastal land as marginal land is used for agricultural cultivation with plant management technology in the form of application of fertilizers and plant varieties that are resistant to disease pests.

The level of welfare of farmers households can be seen in addition to the amount and type of income can also be seen from the income distribution of various income groups of farmers households. Income distribution will be able to illustrate the imbalance of the level of welfare of farm households. The higher income distribution, the more unequal income and the possibility of income inequality between one farmer household and another farmer household (Nasir et.al., 2015). In addition, according to Maipita (2014) in Paradise and Cornella (2014) states that inequality can occur due to differences in the mastery of resources.

This study aims to (1) determine the farmer's household strategies to support the achievement of sustainable livelihoods (2) find out the unequal distribution of farmers' income based on the livelihood strategies used by farm households

\section{MATERIALS AND METHODS}

\section{Study area}

This research was conducted in Sanden Subdistrict, Bantul Regency as one of the sub-districts that has the largest coastal agricultural land area in the Special Region of Yogyakarta. Sanden District, which consists of four villages, was chosen by Srigading Village as a research location with a purposive sampling method.

\section{Respondents}

The study population was farmers who owned agricultural plots and were selected by 30 people as respondents using the simple random sampling method.

\section{Data analysis}

\section{Farmers' Household Strategies for Achieving} Sustainable Livelihoods

The livelihood strategies chosen by farm households including survival, console, or accumulation strategies can be determined by doing a descriptive analysis. The classification of strategies based on household income of farmers is obtained by the following formula:

- Survival strategy: household income <mean - (1/2 standard deviation)

- Consolidation strategy: between a survival strategy and an accumulation strategy

- Accumulation strategy: household income> mean + (1/2standard deviation)

Inequality of Farmer Income Distribution Based on Livelihood Strategies used by Farmers' Households

\section{Gini Index}

The size of the distribution used is the Gini index. The Gini index model (Gini Ratio) can be written as follows:

$$
\mathrm{RG}: 1-\Sigma \mathrm{fi}\left(\mathrm{Y}^{*}{ }_{\mathrm{i}}+\mathrm{Y}^{*_{\mathrm{i}-1}}\right)
$$

Information:

$\mathrm{RG}=$ Gini coefficient ratio

$\mathrm{i} \quad=$ number of classes / classes / income groups

$\mathrm{Y}^{*}{ }_{\mathrm{i}}=$ cumulative relative amount of income in the class / class i

$\mathrm{Y}^{*} \mathrm{i}-1=\mathrm{Y} * \mathrm{i}$ class before $\mathrm{i}$-class

$\mathrm{fi}=$ the number of relative frequencies of income classified

To provide an assessment of the high and low income distribution inequality, the following Oshima criteria are used:

1) Gini Index $<0,4$ shows the inequality of low income distribution

2) Gini Index between 0,4-0,5 shows the current inequality of income distribution

3) Gini Index $>0,5$ shows the high income distribution savings.

\section{Lorenz Curve}

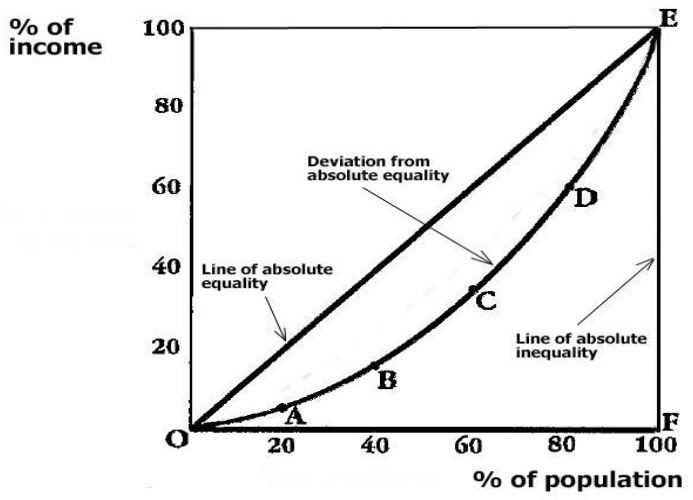

Figure 1. Lorenz Curve.

\section{RESULTS AND DISCUSSION}

Farmers' Household Strategies to Support Achievement of Sustainable Livelihoods

The strategy taken to achieve the livelihoods of farm households can be calculated using the total income of farm households. Grouping strategies chosen by farmers in the sustainability of their livelihoods can be seen in table 1 .

Table 1. Percentage of Farmer Households According to Livelihood Strategies in Sanden District.

\begin{tabular}{|c|c|c|}
\hline Strategy & Total & Percentage (\%) \\
\hline Survival & 11 & 36.7 \\
\hline Consolidation & 13 & 43.3 \\
\hline Accumulation & 6 & 20.0 \\
\hline Total & 30 & 100.0 \\
\hline
\end{tabular}


From the research carried out, the average value and standard deviation of farmers' household income in Sanden Sub district were IDR 61,755,562 and IDR $24,079,830$. Classification is done from the calculation of total household income obtained that the majority of farm households have a livelihood strategy a consolidation strategy (43.3\%). Farmer households with a consolidated strategy generally have sufficient assets to support their livelihoods. The income earned is also relatively high when compared to farm households with a survival strategy. Consolidated farm households can also develop themselves in the use of assets for mediumterm purposes. In general, farmers who carry out a consolidation strategy are farmers who use coastal land to increase control of agricultural land. Coastal land which is a marginal land is planted with chili plants that have high selling value and are suitable to be planted in coastal areas. Survival households (36.7\%) have limited resources and assets. The income earned is based on the expenditure of labor with limited skills. Households with a survival strategy choose to work extra to meet the needs of the household, namely by working odd jobs as farm laborers and construction workers.

Farmer households have accumulated strategies (20\%) have high natural, physical, financial, human and social assets. Accumulated households with owned assets can increase their welfare through productive activities. The productive activities chosen by the accumulated household are aimed at the long term in order to increase the livelihood component they have. In addition, accumulated farmers' households usually carry out their economic activities assisted by laborers and their neighbors. Farmer households with accumulation strategies have extensive land tenure, especially paddy fields. Rice fields are planted with rice and shallots so that they have a high income because of the good selling value of shallots. The component of household livelihood consists of assets, access and activities (Pratiwi \& Hardyastuti, 2011; Yang et al., 2018), from these components the asset most often used by farmers as a livelihood strategy(Wijayanti, Baiquni, \& Harini, 2016).

\section{Inequality of Farmer Income Distribution Based on} Livelihood Strategies Used by Farmers' Households

The unequal distribution of farmers' household income is seen using the Gini index analysis and the Lorenz curve. Equitable distribution of farmer's household income with this index can be seen in table 2 .

Table 2. Gini Index of Farmer Household Income in Sanden District, Bantul Regency.

\begin{tabular}{lcc}
\hline Information & Gini Index & Level of Inequality \\
\hline $\begin{array}{l}\text { Total Farmer's } \\
\text { Household Income }\end{array}$ & 0.443 & Moderate \\
\multicolumn{2}{l}{ Source: Primary Data Analysis }
\end{tabular}

From the results of the analysis it can be seen that the household income of farmers is included in the category of inequality, one of which is due to differences in the mastery of farms owned by farmers. The difference in land area cultivated by farmers influences the productivity and income of farming. In addition, the planting pattern in one year that is cultivated also affects the farming income, because the treatment of each type of plant is different so that the costs incurred in the form of labor and production tools costs are different. Generally farmers plant shallots for one to two seasons in one year, and plant rice for paddy fields. Farmers who don't have extensive land tenure, only plant shallots and vegetables in the form of eggplants on the coastal land whose ownership belongs to the Yogyakarta Palace.

Judging by other methods commonly used besides using the Gini index, the level of inequality of farmers' income distribution is by the Lorenz Curve.

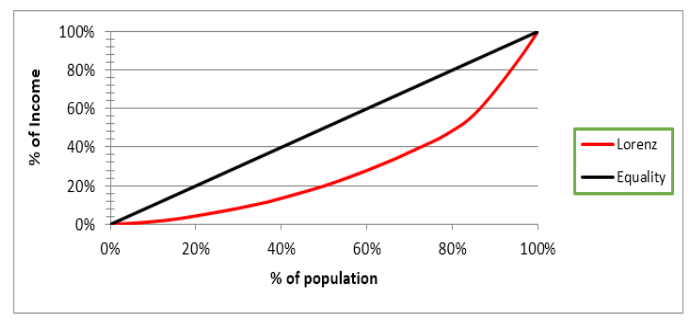

Figure 2. Lorenz Curve Distribution of Farmer Household Income in Sanden District, Bantul Regency. (Source: Primary Data Analysis)

The more convex curve formed by the slope line $\left(45^{\circ}\right)$ the more unequal distribution of farmers' income. If the Lorentz Curve is formed near the equilibrium line, it can be interpreted that the income distribution of farmers is more evenly distributed. From Figure 2, it can be seen that the income of farmers in the distribution of farmers experiences inequality, but this can be seen from the distance of the curve to the equilibrium line. There is a negative quadrant in the curve because there is a minus farmer's household income so that the convex direction of the curve is partly included in the negative quadrant, but only a small proportion of households.

\section{CONCLUSION}

The strategy of farmer households in Sanden Subdistrict to support the achievement of the largest sustainable livelihoods is in the form of a consolidation strategy, and an unequal distribution of income based on the livelihood strategies used by farmer households, namely moderate distribution of inequality.

\section{REFERENCES}

BPS Bantul Regency. (2018). Bantul Regency in Figures 2018. Yogyakarta: BPS Bantul Regency. 
BPS Provinsi Daerah Istimewa Yogyakarta. (2019). Daerah Istimewa Yogyakarta in Figures 2019. Yogyakarta: BPS Provinsi Daerah Istimewa Yogyakarta.

Firdaus, M. dan Witomo, C.M. (2014). Analisis Tingkat Kesejahteraan dan Ketimpangan Pendapatan Rumah Tangga Nelayan Pelagis Besar di Sendang Biru, Kabupaten Malang, Jawa Timur. J. Sosek KP, 9(2), 155-168.

Hermanto. (2017). Pengentasan Kemiskinan Di Perdesaan: Pengembangan SDM, Penguatan Usaha, dan Inovasi Pertanian. Forum Penelitian Agro Ekonomi, 35(2), 139-150.

Mulyono, J., \& Munibah, K. (2017). Strategi Pembangunan Pertanian Di Kabupaten Bantul Dengan Pendekatan a'Wot. Jurnal Pengkajian Dan Pengembangan Teknologi Pertanian, 19(3), 199-211. https://doi.org/10.21082/jpptp.v19n3.2016.p199-211

Nasir, Zahri, I., Mulyana, A., Yunita. 2015. Analisis Struktur dan Distribusi Pendapatan Rumah Tangga Petani di Lahan Rawa Lebak. Agrisep, 14 (1) 97-107.
Nurwidiani, T., \& R, R. (2019). Strategi Penghidupan Masyarakat Transmigrasi Perkebunan Inti Rakyat (PIR) dan Non PIR di Kecamatan Hutaraja Tinggi, Kabupaten Padang Lawas, Sumatera Utara. Jurnal Bumi Indonesia, 8(1), 1-9.

Pratiwi, L. F. L., \& Hardyastuti, S. (2011). Analisis Ekonomi Rumah Tangga Petani Nelayan Dalam Mendukung Strategi Penghidupan Berkelanjutan Kawasan Pantai Baron Kabupaten Gunungkidul. Agro Ekonomi, 18(1), 91-104.

Wijayanti, R., Baiquni, M., \& Harini, R. (2016). Strategi Penghidupan Berkelanjutan Masyarakat Berbasis Aset di Sub DAS Pusur, DAS Bengawan Solo. Jurnal Wilayah Dan Lingkungan, 4(2), 133-152. https://doi.org/10.14710/jwl.4.2.133-152

Yang, L., Liu, M., Lun, F., Min, Q., Zhang, C., \& Li, H. (2018). Livelihood assets and strategies among rural households: Comparative analysis of Rice and Dryland Terrace Systems in China. Sustainability (Switzerland), 10(7), 1-18. https://doi.org/10.3390/su10072525 